\title{
THERAPY OF CHRONIC NASAL DISEASE IN THE DOG
}

\author{
T. FICHTEL, Z. KNOTEK \\ Small Animal Clinic, Faculty of Veterinary Medicine, University of Veterinary \\ and Pharmaceutical Sciences, Brno, Czech Republic
}

Received July 27, 2000

Accepted February 7, 2001

\begin{abstract}
Fichtel T., Z. Knotek: Therapy of Chronic Nasal Disease in the Dog. Acta Vet. Brno 2001, 70: 83-89.

The study includes a total of 61 dogs affected with chronic nasal disease. Various treatment procedures were employed depending on the aetiology and extent of the process. The aim was to check and evaluate different forms of therapy of chronic nasal disease in the dog. Bacterial rhinitis cases were treated in a conservative way using antibiotics (amoxycillin, ceftazidime) and chemotherapeutics (enrofloxacin) for 4 to 5 weeks; mycotic rhinitis cases required treatment by antimycotics (ketoconazole) for 6 to 7 weeks. It was necessary to change the antibiotic drug during the bacterial rhinitis therapy in 5 patients. Surgical treatment of the chronic nasal disease was selected in 47 dogs. A total of 5 dorsal rhinotomy cases resulted in a neoplasm finding and extirpation. Periapical granulomas communicating with the nasal cavity caused chronic rhinitis in 21 dogs. A total of 28 and 11 dogs were treated because of the periapical granuloma of the maxillary fourth premolar (P4) and the maxillary canine tooth (C), respectively. In all, 16 extractions of affected teeth and 5 ventral rhinotomies were performed. Oronasal fistulas on the $\mathrm{C}$ position were in 4 cases treated using the double flap technique and in 6 cases closed by buccal mucosa. Foreign bodies were removed from the nasal cavity with respect to the size and localisation using a rigid endoscope in 4 cases or rhinotomy ( 4 dorsal and 2 ventral rhinotomy cases). Conservative and surgical approaches are effective in the treatment of chronic nasal diseases in the dog. Selection of proper therapeutic procedures depends on individual evaluation of each case.
\end{abstract}

Rhinitis, intranasal neoplasia, rhinotomy

Nasal diseases in the dog and cat are caused by a variety of aetiological factors, diagnostic and therapeutic procedures of which require a thorough work-up (Forbes Lent and Hawkins 1992; Ogilvie and LaRue 1992; Van Pelt and Mc Kiernan 1994; Caniatti et al. 1998ab; Knotek et al. in press). The periapical granuloma, sequel to the pulpitis, is a relatively common problem. They form an inflammatory lesion around the root apex in the periodontium that is followed by circumscribed osteomyelitis and extension of the inflammation into the alveolar wall (Marretta 1992). The process may then extend into the subcutaneous tissue or nasal cavity.

Therapy of chronic rhinitis consists of various forms (Pavletic and Clark 1991). Surgical treatments including turbinectomy, despite the hope for a radical solution, are not considered useful by some authors (Gaskell and Gaskell 1997). Conservative therapy based on oral administration of antibiotics or antimycotics results in varying efficacy in dependence on the rate of patient affection and the selection of the preparation $(50 \%$ in ketoconazole and up to $70 \%$ in itraconazole and fluconazole). The last two preparations mentioned, due to their higher efficacy and lower toxic effects on the organism, are superior to ketoconazole (W olf 1992; Nors w or thy 1995). Fluconazole, in addition to it, penetrates well into the CNS. Therapy lasts more than 8 weeks and, as a rule, is continued one month past clinical remission. Good results may be achieved by repeated administration of clotrimazole (Antifungol liq., Hexal AG) or enilconazole into the affected area using a catheter (McCullough et al. 1998). It is worth passing the catheter under endoscopic 
guidance. It is not possible to enter the sinus frontalis endoscopically in healthy dogs, however, in patients suffering from advanced aspergillosis the endoscope can be passed as far as this area because of marked osteolysis.

Extensive inflammatory lesions and large foreign bodies or neoplasia are removed from the nasal cavity by rhinotomy. Dorsal or ventral approaches are to be considered in dependence on the localisation of the process (Holmberg et al. 1989; B ojrab 1990). Simple endoscopic procedures (Vo kurka et al. 1998), similar to those ones used in paediatrics, may be employed for the removal of smaller foreign bodies from the nasal cavity in the dog and cat.

The aim of this paper is to compare various forms of therapy of chronic nasal diseases in 61 dogs. Attention was paid to conservative therapy and surgical procedures (in 47 patients) indicated on the basis of endoscopic examination and laboratory testing.

\section{Materials and Methods}

Patients

A total of 61 dogs suffering from chronic nasal diseases were included in the project. The patients were referred to our clinic by co-operating veterinarians from around the Czech Republic. Basic anamnestic data (Knotek et al. in press) were recorded and results of previous examinations evaluated. Table 1 presents a survey of patients.

Table 1

Characteristics of dogs suffering from chronic nasal diseases $(n=61)$

\begin{tabular}{|c|l|l|}
\hline \multicolumn{2}{|c|}{ Disease aethiology } & Discharge quality \\
\hline $\begin{array}{c}\text { Bacterial } \\
\text { rinitis } \\
(16)\end{array}$ & $\begin{array}{l}\text { Staphylococcus intermedius, } \text {. } \\
\text { aureus, Streptococcus canis, } \\
\text { Pasteurella multocida, Pseudomonas aeruginosa }\end{array}$ & $\begin{array}{l}\text { Initially clear, later } \\
\text { mucopurulent }\end{array}$ \\
\hline $\begin{array}{c}\text { Mycotic } \\
\text { rhinitis } \\
(7)\end{array}$ & $\begin{array}{l}\text { Aspergillus niger, A. fumigatus, } \\
\text { A. ustus, Alternaria sp., Rhizopus stolonifer }\end{array}$ & Mucopurulent \\
\hline $\begin{array}{c}\text { Neoplasia } \\
(9)\end{array}$ & $\begin{array}{l}\text { Osteosarcoma, lymphosarcoma, } \\
\text { adenocarcinoma, adenoma }\end{array}$ & $\begin{array}{l}\text { Mucopurulent and blood } \\
\text { tinged }\end{array}$ \\
\hline $\begin{array}{c}\text { Foreign body } \\
(8)\end{array}$ & Awns, grass spikes, twigs & Mucopurulent \\
\hline $\begin{array}{c}\text { Disorders of teeth } \\
(21)\end{array}$ & Periapical granuloma & $\begin{array}{l}\text { Initially clear, later } \\
\text { mucopurulent }\end{array}$ \\
\hline
\end{tabular}

\section{Conservative therapy}

Dogs of the studied group were on the basis of previous examinations diagnosed as affected in 16 and 7 cases by bacterial and mycotic rhinitis, respectively. Based on sensitivity testing of causative agents to antibiotics and chemoterapeutics, therapy using amyxycillin (Synulox 500 tbl. ad us. vet., Pfizer, $12.5 \mathrm{mg} / \mathrm{kg}$, p.o., b.i.d.), and enrofloxacin (Baytril tbl. ad us. vet., Bayer, $5-10 \mathrm{mg} / \mathrm{kg}$ p.o.) was performed. Ceftazidime (Fortum, Glaxo Wellcome, $500 \mathrm{mg}$ inj. sicc., $30 \mathrm{mg} / \mathrm{kg}$ s.c., b.i.d. or t.i.d.) was used in complicated cases. As far as antimycotic agents are concerned, therapy by ketoconazole (Oronazol tbl., Krka d.d., $10 \mathrm{mg} / \mathrm{kg}$, p.o., b.i.d.) was evaluated. Therapy was long-term; the owner was recommended to administer the drug for 3 to 4 weeks.

Preoperative preparation

The operation was preceded by 12 hours of fasting. Standard preoperative examination of the patient was performed (temperature, pulse and respiration rate evaluation, cardiovascular function check). Attention was paid to the current quantity and quality of nasal discharge, deformities of nostrils and facial parts of the skull, head carriage, ocular discharge, status of the maxillary teeth periodontium and occurrence of palatal and jaw clefts.

Anaesthesia

An endotracheal tube was passed before procedures in the nasal cavity to prevent aspiration of blood, secretions and lavage solutions. Anaesthesia was selected depending on the state of the patient and the presumed duration of the procedure. A combination of diazepam (Seduxen inj., Gedeon Richter Ltd., $0.5-2 \mathrm{mg} / \mathrm{kg}$ i.v.) or medetomidine 
(Domitor inj. ad us. vet., Orion - Farmos, $0.01 \mathrm{mg} / \mathrm{kg}$ i.v.) with butorphanol (Beforal, Léčiva a.s., $0.2 \mathrm{mg} / \mathrm{kg}$ i.v.) proved to be effective for the induction to anaesthesia. General anaesthesia was then induced by propofol (Diprivan, Zeneca Ltd., $1-2 \mathrm{mg} / \mathrm{kg}$ i.v.). The above-mentioned combination was also selected for the introduction to the inhalation anaesthesia (Halothane liq., Léčiva). The condition of the patient was monitored using a pulse oximeter (SurgiVet V3301) during the anaesthesia.

\section{Endoscopy}

Minute foreign bodies were removed from the nasal cavity of patients using endoscopic forceps (67161 Z, Karl Storz, Tuttlingen) under the guidance of a rigid endoscope (Hopkins, diameter $2.7 \mathrm{~mm}, 18 \mathrm{~cm}$, Karl Storz, Tuttlingen).

\section{Rhinotomy}

The operation field for the dorsal rhinotomy was prepared by hair clipping and scrubbing using chlorhexidine (Novalsan Surgical Scrub sol. ad us. vet., Fort Dodge). Eyes, lying in the near vicinity of the operation area, were protected from chemical irritation and microbial contamination by an ophthalmic ointment (Ophtalmo-Azulen ung. opth. Spofa). After draping, a skin incision was made parallel to the long axis of the nose, paramedially on the affected side. In bilateral rhinotomy cases, the incision was located in the medial line of the nose. When opening the sinus frontalis, the incision was drawn in between the medial eye canthi in a curve over os frontale, which the sinus frontalis lateralis is located in. The subcutaneous tissue is released, the bone denuded and then the periost is elevated in the whole extent of the rhinotomy area using a periosteal elevator. For the purpose of entering the nasal cavity in a smaller extent (through a trepanation hole), bone tissue was burred off up to the submucosa of the nasal cavity. In cases, when the mucosa remained intact, the nasal cavity was entered by an incision. When performing rhinotomy of a greater extent, the wall was ablated using a bone saw and a chisel. The nasal cavity was then entered by reflecting the free bone segment. Following the pathological lesion removal and the nasal cavity revision, the excised bone segment was replaced and sutured into place by several wire sutures (at least one suture on each side). If the bone was removed by a burr, the mucosa and periost were sutured together. Both layers were sutured using monofilament absorbable material (PDS, Ethicon). The subcutaneous tissue was sutured by simple continuous or interrupted suture using braided absorbable material (Vicryl, Ethicon), the skin by intradermal suture (PDS, Ethicon) or simple interrupted suture (Ethilon, Ethicon).

Ventral rhinotomy approach was selected when the process was limited to the ventral part of the nasal cavity only or was related to disorders of teeth. The patient was positioned in dorsal recumbency with the mouth wide open. When teeth and the surrounding tissue were intact, the procedure was started by a longitudinal incision of the hard palate mucosa along the maxillary teeth. Both incision ends were enlarged by incisions perpendicular to the median line of the palate and a flap of mucosa together with the periost was reflected off. Bone tissue was removed using a burr and a chisel. After the incision of the mucosa in the nasal cavity, the following procedure depended on the characteristics of the process. The incision was closed in two layers using absorbable monofilament material (PDS, Ethicon) and simple continuous suture. The surface of the mucosa was treated by the same material in a simple interrupted pattern.

\section{Teeth extractions}

Tooth extraction was indicated when pathological changes in the nasal cavity were caused by an advanced process on the tooth and its periodontium. Such problems were almost exclusively restricted to maxillary canines, fourth premolars and first molars affected by periapical abscess formation. Tooth extraction resulted in formation of a communication between the oral and nasal cavities called "oronasal fistula." The fistula was enlarged as needed for the removal of all affected tissue from the tooth socket and the nasal cavity. This was done using a burr. The hole was then closed only on the side of the oral cavity using a buccal mucosa flap or a transposed flap of the hard palate mucosa. A combination of two methods, the so-called double flap technique (Marretta 1992), proved to be effective when the mucosa of the palate was reflected so that one side of the flap neighbouring with the incision remained connected with the bone. The flap was turned over the wound and sutured to its margins using the simple interrupted pattern and monofilament absorbable material (PDS, Ethicon). When placing the sutures, we did not drive the needle through the surface of the mucosa but only the submucosa on either side. In this way, we achieved excellent wound margin apposition.

The buccal mucosa was prepared in such a way that from the medial and distal margin of the wound there were made longitudinal incisions perpendicular to the axis of the jaw, a flap of needed size was created by blunt dissection and transposed over the wound. The wound in the oral cavity was treated until its healing using local drugs containing chlorhexidine (Gingisan a.u.v., Chassot) and means of epithelisation (Solcoseryl dental adhesive paste, Solco Basel AG).

\section{Results}

Long-term therapy was successful in treating 16 cases of bacterial and 7 cases of mycotic rhinitis. On average, the necessary duration of therapy in bacterial and mycotic rhinitis 
patients was 4 to 5 weeks and 6 to 7 weeks, respectively. It was necessary to change the antibiotic drug during therapy of 5 patients (two of them had allergic reactions on amoxycillin and enrofloxacin; in three cases there was no health status improvement). We achieved successful results using ceftazidime (Table 2) in these cases.

Table 2

Conservative treatment of chronic rhinitis $(n=23)$

\begin{tabular}{|l|c|l|l|}
\hline Aethiology & $\mathrm{n}$ & Drugs & $\begin{array}{l}\text { Average length } \\
\text { of therapy }\end{array}$ \\
\hline $\begin{array}{l}\text { Staphylococcus intermedius, S. aureus, } \\
\begin{array}{l}\text { Streptococcus canis, Pasteurella multocida, } \\
\text { Pseudomonas aeruginosa }\end{array}\end{array}$ & 16 & $\begin{array}{l}\text { Amoxycillin, } \\
\text { enrofloxacin, } \\
\text { ceftazidime }\end{array}$ & $4-5$ weeks \\
\hline $\begin{array}{l}\text { Aspergillus niger, A. fumigatus, A. ustus, } \\
\text { Alternaria sp., Rhizopus stolonifer }\end{array}$ & 7 & Ketoconazole & $6-7$ weeks \\
\hline
\end{tabular}

Foreign bodies were removed from the nasal cavity of 4 dogs using endoscopic forceps under the guidance of a rigid endoscope (Table 3). In two cases, with foreign body removed from the nasal cavity using rhinoscopy, there was some bleeding from the affected part shortly after the removal. This bleeding was immediately stopped mechanically. These patients were administered antibiotics (amoxycillin per os) for 10 to 14 days. Their health status quickly returned to normal and there was no complication.

Table 3

Endoscopic removal of foreign bodies $(n=4)$

\begin{tabular}{|l|l|l|}
\hline Foreign body & Localisation & Complications \\
\hline Awn & $\begin{array}{c}\text { Central nasal meatus in the } \\
\text { middle area of the nasal cavity }\end{array}$ & - \\
\hline Awn & $\begin{array}{c}\text { Ventral nasal meatus in the } \\
\text { caudal area of the nasal cavity }\end{array}$ & $\begin{array}{l}\text { Short-time bleeding after the foreign body } \\
\text { removal }\end{array}$ \\
\hline Part of a twig & $\begin{array}{c}\text { Central nasal meatus in the } \\
\text { middle area of the nasal cavity }\end{array}$ & $\begin{array}{l}\text { Short-time bleeding after the foreign body } \\
\text { removal }\end{array}$ \\
\hline Needle-leaves & $\begin{array}{c}\text { Central nasal meatus in the rostral } \\
\text { area of the nasal cavity }\end{array}$ & - \\
\hline
\end{tabular}

Periapical granuloma draining to the nasal cavity as a cause of chronic rhinitis was diagnosed in $21 \mathrm{dogs}$ of our group of patients. We treated a total of $28 \mathrm{dogs}$ affected by the periapical granuloma of the fourth maxillary premolar (P4) and 11 dogs with the maxillary canine (C) periapical granuloma. All affected premolars (P4) had damaged crowns and open pulp cavities. In 12 cases there was a communication between the palatal alveolus and the nasal cavity. As far as canines are concerned, 5 of them were abraded and 7 chipped off. In 9 cases the granuloma communicated with the nasal cavity. We performed 16 tooth extractions and 5 ventral rhinotomies. Oronasal fistulas on the $\mathrm{P} 4$ position were covered by the buccal mucosa. All wounds healed without dehiscence. Oronasal fistulas on the C position were in 4 cases treated by the technique of a double flap without dehiscence and in 6 cases covered by the buccal mucosa with dehiscence of 2 wounds.

We also performed 14 dorsal and 3 ventral rhinotomies during this period. There were 
found and excised neoplasia during 5 rhinotomies, foreign bodies in 4 cases and 2 cases resulted in no specific findings. Trepanation of frontal sinuses as well as draining was performed in 3 dogs. The nasal cavity was drained in all cases of neoplasia excision. Two ventral rhinotomies were performed in order to remove foreign bodies; one such case was without a specific finding (Table 4).

Table 4

Surgery as a treatment of chronic rhinitis cases $(n=47)$

\begin{tabular}{|l|c|l|}
\hline Surgical procedure & $\begin{array}{c}\text { Number of patients } \\
\mathrm{n}\end{array}$ & Indication \\
\hline Ventral rhinotomy & 2 & Foreign body removal \\
Dorsal rhinotomy & 4 & \\
\hline Ventral rhinotomy & 1 & Neoplasia excision \\
Dorsal rhinotomy & 5 & \\
\hline Dorsal rhinotomy & 2 & Probatory rhinotomy \\
\hline Dorsal rhinotomy & 2 & Non-specific granuloma excision \\
\hline Double flap technique & 4 & Oronasal fistula \\
Buccal mucosa flap cover & 6 & \\
\hline Tooth extraction & 16 & Periapical granuloma \\
Ventral rhinotomy & 5 & \\
\hline
\end{tabular}

Discussion

Therapy of bacterial rhinitis in dogs commonly employs long-term therapy using antibiotics, corticosteroids, antihistaminics, and nasal cavity lavage. Many cases, however, show positive results only during the period of administration of the above-mentioned drugs and after the treatment is discontinued, the complications return (Nels on 1998). As far as our group of dogs is concerned, positive results were achieved by long-term administration of amoxycillin, enrofloxacin and ceftazidime. It was necessary to change the antibiotic drug, due to allergic reactions of the patient $(12.5 \%)$ or insufficient efficacy of the drug $(18.8 \%)$, in nearly one third of cases $(31.3 \%)$. Cephalosporins of the first generation and sulphonamides (Harvey 1984) may be considered. Our patients were successfully managed by ceftazidime, i.e., a cephalosporin of the third generation. Mycotic rhinitis was in 7 dogs successfully treated by long-term administration of ketoconazole per os. Administration of antimycotics directly to the nasal cavity is rather a more complicated, nevertheless, very effective method of therapy of chronic mycotic rhinitis. In such a case a permanent catheter is placed and fixated in the frontal sinus and nasal cavity and is used as a means for the administration of antimycotic drug solutions twice daily for a week or two (McCullough et al. 1998).

When the complications in the nasal cavity are secondary to diseases of teeth, i.e., of maxillary canines, fourth premolars and first molars in particular, the therapy is aimed at the treatment of teeth and periodontium. This includes endodontic treatment and root resection of the affected tooth or its extraction and closure of the oronasal fistula (Marretta 1992). The second possibility is more frequently used, because in this stage of the process the periodontium and maxillary bone are so damaged that it is not possible to salvage the tooth. If the periodontium is seriously damaged, we prefer tooth extraction. The postextraction wound treatment is then similar as in the periapical granuloma. The periapical granuloma draining to the nasal cavity as a cause of chronic rhinitis in the dog amounted to 21 cases in 
our group of patients. Canines were abraded in 5, and chipped off in 7 dogs. In 9 dogs the granuloma was connected with the nasal cavity. In dependence on the localisation of the process it is necessary to consider either ventral or dorsal rhinotomy approach (Holmberg et al. 1989; Bojrab 1990). We performed 16 tooth extractions of damaged teeth and 5 ventral rhinotomies.

Simple endoscopic procedures (Vokurka et al. 1998) may be used to remove minute foreign bodies from the nasal cavity in the dog as in paediatric cases.

Our results indicate that conservative and surgical approaches are effective in the treatment of chronic nasal diseases in the dog and the proper selection of therapeutic procedures requires case evaluation on an individual basis.

\section{Terapie chronického onemocnění dutiny nosní u psa}

Do sledování bylo zařazeno 61 psů trpících chronickou rinitidou. Byla volena rozdílná řešení chronických zánětů $\mathrm{v}$ závislosti na etiologii a rozsahu procesu. Cílem bylo prověřit a zhodnotit různé formy terapie chronických onemocnění dutiny nosní u psů. Bakteriální rinitidy byly řešeny konzervativní terapií antibiotiky (amoxycilin, ceftazidim) a chemoterapeutiky (enrofloxacin) po dobu 4 - 5 týdnů; mykotické rinitidy vyžadovaly podávání antimykotika (ketokonazol) po dobu $6-7$ týdnů. V 5 případech bylo $\mathrm{v}$ průběhu terapie bakteriální rinitidy nutno změnit antibiotikum. Ve 47 př́ípadech bylo voleno chirurgické řešení chronického onemocnění dutiny nosní. U 5 dorzálních rinotomií byl nalezen a exstirpován novotvar. Periapikální granulom komunikující s dutinou nosní byl příčinou chronické rinitidy u 21 psů. Celkově bylo ošetřeno 28 psů s periapikálním granulomem čtvrtého premoláru horní čelisti $\left(\mathrm{P}_{4}\right)$ a 11 psů s periapikálním granulomem špičáku horní čelisti (C). Bylo uskutečněno 16 extrakcí poškozeného zubu a 5 ventrálních rinotomií. Oronazální píštěle na místě $C$ byly ve 4 případech ošetřeny využitím techniky dvojitého laloku a v 6 případech překryty bukální sliznicí. Cizí tělesa byla z dutiny nosní odstraněna podle velikosti a lokalizace ve 4 prrípadech pomocí rigidního endoskopu nebo rinotomií (4 dorzální rinotomie, 2 ventrální rinotomie). Konzervativní i chirurgická terapie jsou účinným řešením chronických onemocnění dutiny nosní u psů. Správná volba terapeutického přístupu závisí na individuálním posouzení každého př́ípadu.

\section{Acknowledgements}

This study was supported by University of Veterinary and Pharmaceutical Sciences Brno (grant IGA VFU 31/2000/FVL). The authors are grateful to MVDr. Petr Raušer for his technical assistance during the anaesthesia of patients and operative procedures.

\section{References}

BOJRAB, M. J. 1990: Current techniques in small animal surgery, 3rd Ed., Philadelphia, Lea \& Febiger , pp. 321326

CANIATTI, M., ROCCABIANCA, P., GHISLENI, G., MORTELLARO, C. M., ROMUSSI, S., MANDELLI, G. 1998a: Evaluation of brush cytology in the diagnosis of chronic intranasal disease in cats. J. Small Anim. Pract. 39: $73-77$

CANIATTI, M., ROCCABIANCA, P., SCANZIANI, E., FINAZZI, M., MORTELLARO, C. M., ROMUSSI, S., MANDELLI, G. 1998b: Nasal rhinosporidiosis in dogs: four cases from Europe and a review of the literature. Vet. Rec. 142: 334-338

FORBES LENT, S. E., HAWKINS, E. C. 1992: Evaluation of rhinoscopy and rhinoscopy-assisted mucosal biopsy in diagnosis of nasal disease in dogs: 119 cases (1985 - 1989). J. Ame. Vet. Med. Assoc. 201: 1425-1429

GASKELL, C. J., GASKELL, R. M. 1997: Chronic nasal and oral diseases in cats. Vet. Quart. 19, Suppl 1: 8-9

HARVEY. C. E. 1984: Therapeutic strategies involuing antimicrobial treatment of the upper respiratory tract in smal animals. J. Amer. Vet. Med. Assoc. 185: 1159

HOLMBERG, D. L., FRIES, C., COCKSHUTT, J., Van PELT, D. 1989: Ventral rhinotomy in the dog and cat. Vet. Surg. 18: 446-449

KNOTEK, Z., FICHTEL, T., KOHOUT, P., BENÁK, J. 2001: Diseases of the nasal cavity in the dog. Aetiology, symptomatology, diagnostics. Acta Vet. Brno 70: 000-000 
MARRETTA, S. M. 1992: Chronic rhinitis and dental disease. Vet. Clin. North. Amer. 22: 1101-1117

McCUlloUGH, S. M., KIERNAN, B. C., GRODSKY, B. S. 1998: Endoscopically placed tubes for administration of enilconazole for treatment of nasal aspergillosis in dogs. J. Amer. Vet. Med. Assoc. 212: 67-69

NELSON, R. W. 1998: Small animal internal medicine. Mosby Inc., St. Louis, $2^{\text {nd }}$ ed., pp. 206-237

NORSWORTHY, G. 1995: Treating chronic nasal discharge in cats. Vet. Med. 90: 1048-1054

OGILVIE, G. K., LaRUE, S. 1992: Canine and feline nasal and paranasal sinus tumors. Vet. Clin. North. Amer. 22: $1133-1144$

PAVLETIC, M. M., CLARK, G. N. 1991: Open nasal and frontal sinus treatment of chronic canine aspergillosis. Vet. Surg. 20: $43-48$

Van PELT, D. R., McKIERNAN, B. C. 1994: Pathogenesis and treatment of canine rhinitis. Vet. Clin. North. Amer. 24: 789-806

VOKURKA, J., ŠLAPÁK, I., HYBÁŠEK, I. 1998: Endoskopické endonazální operace. Acta Fac. Med. Univ Brunensis Masarykianae, Brno, $116 \mathrm{p}$.

WOLF, A. M. 1992: Fungal diseases of the nasal cavity of the dog and cat. Vet. Clin. North. Amer. 22: 1119-113 
Plate XVII

Fichtel T. et al.: Therapy... pp. 83-89

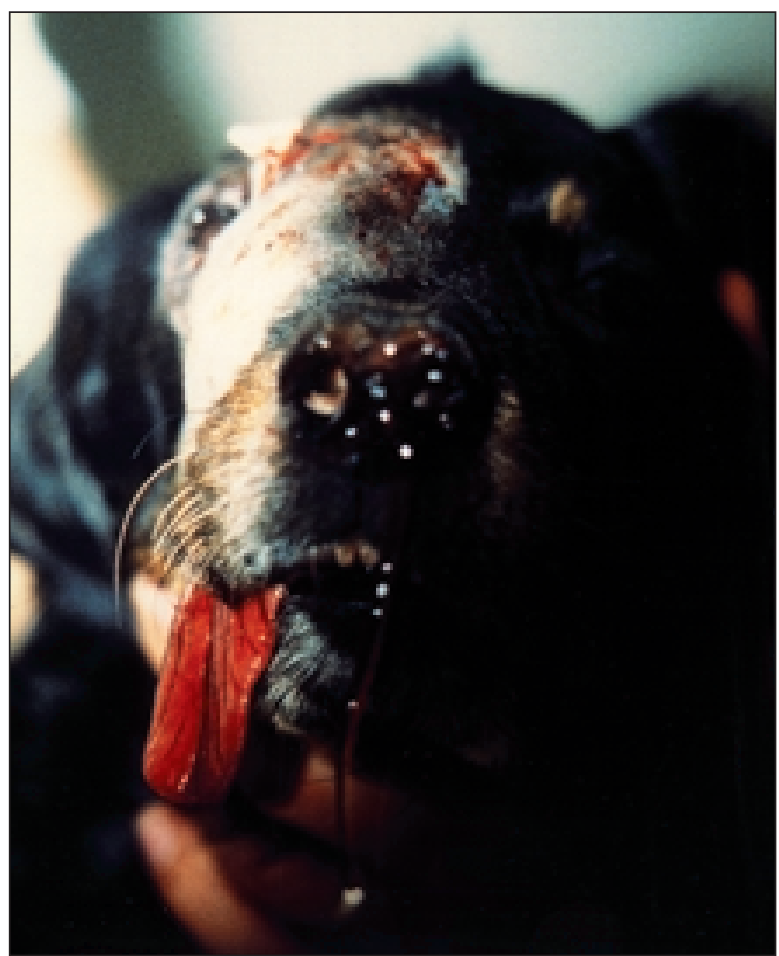

Fig. 1. Osteosarcoma in the nasal cavity. Fistula before surgical treatment.

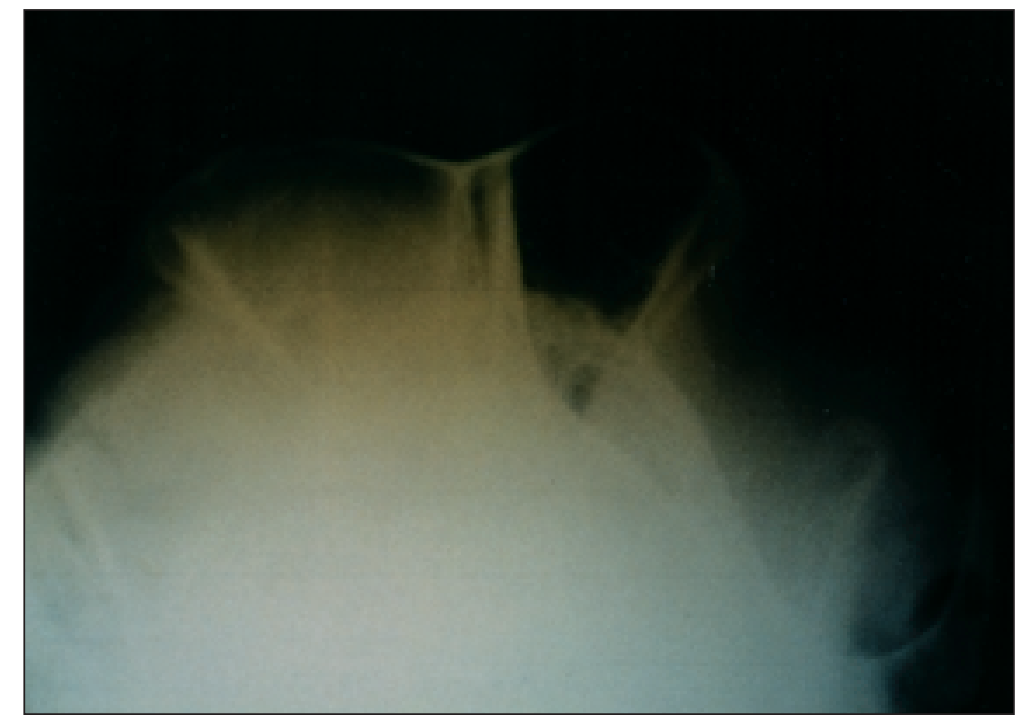

Fig. 2. Unilateral density in the frontal sinus in a dog. 
Plate XVIII

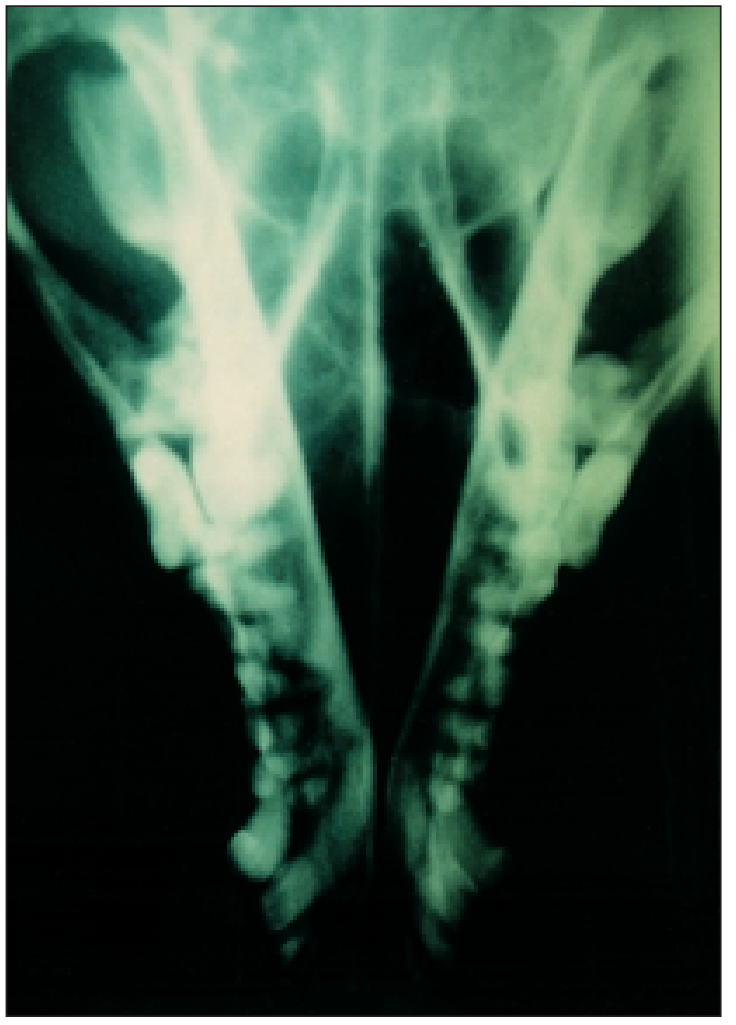

Fig. 3. Unilateral density in the nasal cavity in a dog.

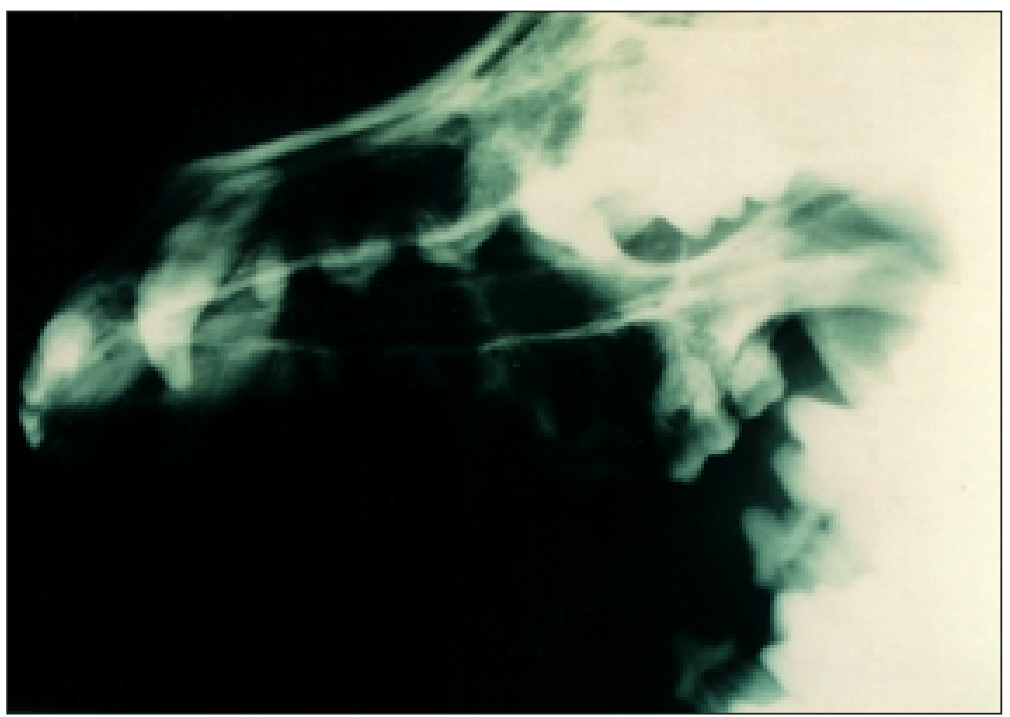

Fig. 4. Periapical granuloma affecting the distal root of P4 
Plate XIX

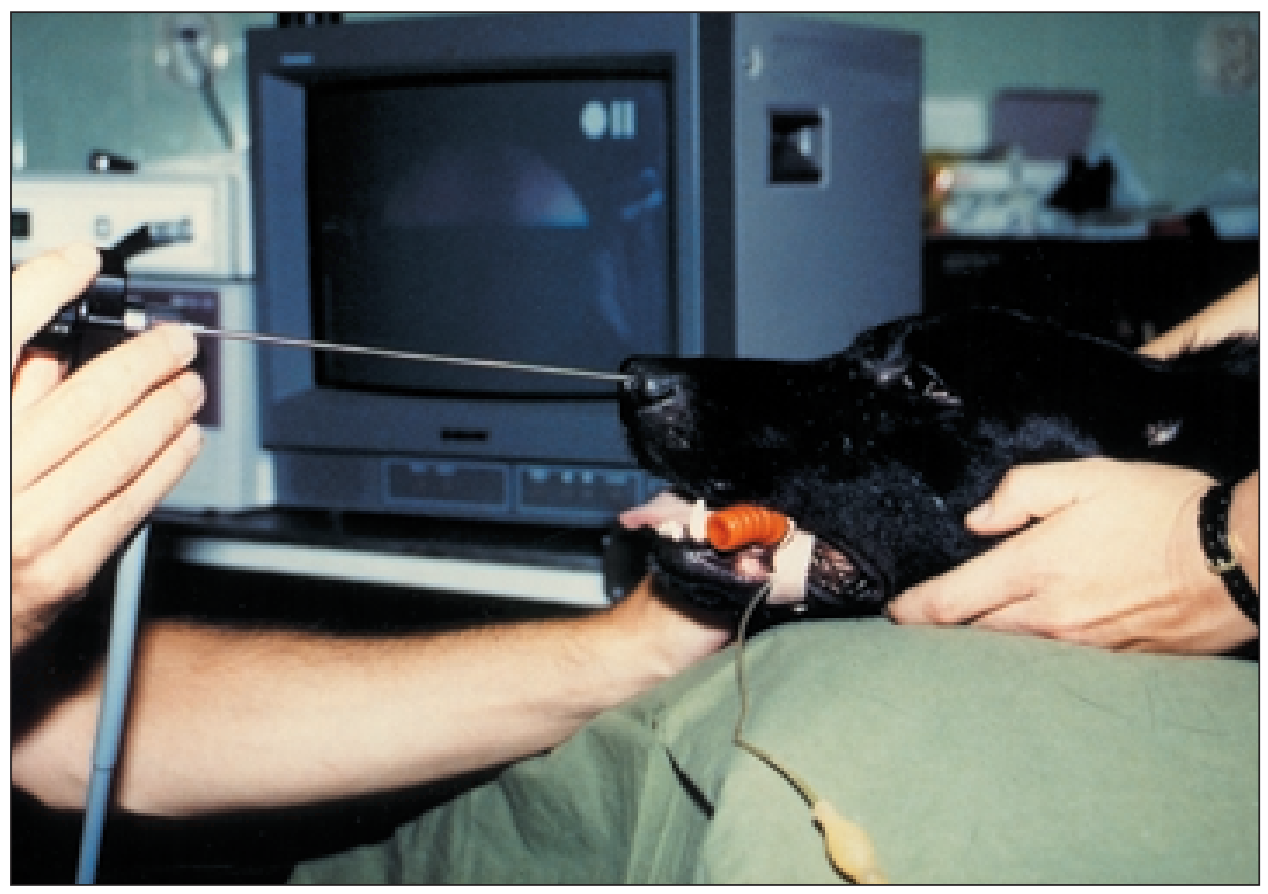

Fig. 5. Examination of the nasal cavity using a rigid endoscope (Hopkins, diameter $2.7 \mathrm{~mm}, 18 \mathrm{~cm}$, Karl Storz) 